Int. J. Dev. Biol. 54: 1099-1106 (2010)

doi: $10.1387 / \mathrm{ijdb} .093057 \mathrm{ko}$

\title{
The placenta as a haematopoietic organ
}

\author{
KATRIN OTTERSBACH ${ }^{*, 1}$ and ELAINE DZIERZAK ${ }^{2}$ \\ ${ }^{1}$ Department of Haematology, Cambridge Institute for Medical Research, University of Cambridge, U.K. and \\ ${ }^{2}$ Erasmus Stem Cell Institute, Department of Cell Biology, Erasmus Medical Center, Rotterdam, The Netherlands
}

\begin{abstract}
The recent description of the placenta as a tissue rich in haematopoietic stem and progenitor cells has not only opened up a whole new line of investigation into how haematopoiesis is regulated in this unique mammalian tissue, but has also resulted in the revisiting of longstanding and yet unanswered questions about the significance of having multiple haematopoietic organs during development. Due to its remarkable capacity for haematopoietic stem/progenitor cell expansion, the study of placental haematopoiesis is also of obvious clinical interest. In the following pages, we summarise what is currently known about the haematopoietic regulatory processes in the murine placenta and describe our most recent data demonstrating that the human placenta, like its murine counterpart, is also a source of haematopoietic stem and progenitor cells throughout development.
\end{abstract}

KEY WORDS: placenta, haematopoietic stem cell, HSC, development

\section{Introduction}

The adult haematopoietic system is a model for the study of the basic processes of cell proliferation, differentiation and selfrenewal. The many steps beginning with the initiating haematopoietic stem cell (HSC) and leading to the production of the various lineages and finally to the mature blood cell types have been described (Weissman and Shizuru, 2008). Cell surface marker characterisation by flow cytometry has made it possible to isolate many of the distinct intermediate progenitor cells of the haematopoietic hierarchy. Yet, new haematopoietic progenitors continue to be found, and challenges to the well-established adult hierarchy are still being made (Adolfsson et al. 2005; Bell and Bhandoola, 2008; Wada et al. 2008).

In contrast, little is known about the origins and differentiation hierarchy of the haematopoietic system during development. In the mouse and other vertebrate embryos, two separate waves of haematopoietic activity have been described, a primitive wave, consisting of primitive macrophages, megakaryocytes and nucleated erythrocytes, and a definitive wave, which includes a number of progenitors with varying degrees of complexity and differentiation potentials (Dzierzak and Speck, 2008). The lineage relationship between the cells of the primitive and definitive waves is unclear, and it is uncertain whether these cells or their descendents can be found in the adult system. It is only the definitive wave that culminates in the appearance of the first adult-type
HSCs at midgestation. The appearance of mature macrophages, megakaryocytes and erythrocytes in the primitive wave precedes the appearance of HSCs in the definitive wave indicating that an alternative and reversed hierarchy exists in the embryo as compared to that in the adult. This reversed embryonic hierarchy suggests that there are no lineage relationships between HSCs and the earlier mature blood cells. It is only after midgestation that an adult-type hierarchy begins to be established.

Currently there is great interest in the origin of HSCs, i.e. the embryonic tissue in which they are first generated, and the precursor cell(s) from which they are derived. During development HSCs can be found in several different haematopoietic territories at overlapping and/or different time points (Fig. 1). The use of different assays and different criteria are further complicating factors in the study of HSC development in the embryo. Experiments carried out in the 1970s using mouse embryos seem to suggest that HSCs and other multipotent haematopoietic progenitors are first generated in the yolk sac (YS) (Moore and Metcalf, 1970; Weissman et al. 1978). This paradigm was challenged by quail-chick embryo grafting experiments, which demonstrated that adult blood derives from an intra-embryonic source (Dieterlen-Lievre, 1975). A similar intra-embryonic source for

Abbreviations used in this paper: AGM, aorta-gonad-mesonephros region; FL, foetal liver; HSC, haematopoietic stem cell; YS, yolk sac.

\footnotetext{
*Address correspondence to: Katrin Ottersbach. Department of Haematology, Cambridge Institute for Medical Research, University of Cambridge, Hills Road, Cambridge CB2 0XY, England UK. Fax: +44-1223-336-827. e-mail: ko268@cam.ac.uk
}

Final, author-corrected PDF published online: 16 July 2010.

ISSN: Online 1696-3547, Print 0214-6282

() 2010 UBC Press

Printed in Spain 
multipotent progenitors and HSCs was eventually identified in mice (Cumano et al. 1996; Medvinsky and Dzierzak, 1996; Muller et al. 1994) and termed the AGM region, as it contains the developing aorta, gonads and mesonephros. Adult-type HSCs, i.e. cells that can repopulate a normal, irradiated adult recipient, are first detected in the AGM at embryonic day (E) 10.5 (Medvinsky and Dzierzak, 1996; Muller et al. 1994), a day earlier than their appearance in the YS. HSCs reside in both tissues only transiently, and their numbers start to decline as stem cells begin to colonise the foetal liver (FL). For the remainder of foetal development, the FL remains the main haematopoietic tissue where HSCs expand in number and differentiate into the various mature blood cell types, before they relocate to the bone marrow (BM) around the time of birth (Fig. 1). More recently, another major source of HSCs in the murine embryo was discovered, the midgestation placenta (Gekas etal.2005; Ottersbach and Dzierzak, 2005). It had been suggested that due to the large numbers of HSCs present in the FL after E12, HSCs from several sources contribute to the colonisation of the FL (Kumaravelu et al. 2002). The placenta was found to contain HSCs starting from E11, with numbers expanding dramatically at E12 and far beyond the number found in the AGM and YS at that point (Gekas et al. 2005; Ottersbach and Dzierzak, 2005). This exciting discovery then raised a number of questions: (1) are the placenta-derived HSCs phenotypically and functionally identical to the ones found in other embryonic tissues?; (2) does the placenta have the capacity to generate HSCs or is it colonised by cells from a different origin?; and (3) what are the stromal components responsible for the dramatic HSC expansion? These questions are only just starting to be tackled, and the following pages will discuss some of the initial findings.

\section{Development of the placenta}

The placenta is a unique mammalian tissue that forms the interface between the maternal and foetal environments. Placenta development is initiated when the allantois, a mesodermal structure that extends from the posterior end of the embryo starting at E7.5, fuses with the chorionic ectoderm at E8.5 (reviewed in Cross et al. 2003; Rossant and Cross, 2001). At this juncture major morphological changes take place that result in the formation of primary villi, which then through further growth and branching develop into the highly vascularised labyrinth region of the placenta. The foetal vessels, including the umbilical vessels, and the associated stroma are contributed by the allantois, while the three layers of trophoblast cells that surround the foetal capillaries and function as a barrier between the maternal and foetal circulation, are derived from the chorion (Simmons et al.
2008). Overlying the labyrinth is the spongiotrophoblast layer, which is thought to derive from the ectoplacental cone and which provides the developing placenta with structural support. The final interface between the foetal and the maternal tissues is formed by a layer of trophoblast giant cells (Fig. 2).

Interestingly, the two precursor tissues of the placenta, the allantois and the chorion, have recently been shown to possess intrinsic haematopoietic potential (Corbel et al. 2007; Zeigler et al. 2006). Already a number of years previously, the avian allantois had been demonstrated in grafting experiments to contribute to adult haematopoiesis (Caprioli et al. 1998; Caprioli et al. 2001). At the same time, similar grafting experiments in mouse embryos showed allantoic contribution to endothelial, but not haematopoietic cells in the host (Downs et al. 1998; Downs and Harmann, 1997). However, recent studies using an in vitro culture of pre-fusion allantois and chorion for 2 days, followed by methylcellulose assays, reveal the intrinsic potential of these tissues to give rise to clonogenic haematopoietic progenitors (Corbel et al. 2007; Zeigler et al. 2006). In addition, the expression of definitive haematopoietic markers can be detected in the early allantois and chorion (see below). Thus, the tissues giving rise to the placenta have haematopoietic progenitor potential, but whether they also possess potential for HSC generation still remains to be determined.

\section{Placental haematopoiesis}

The discovery of HSCs in the mouse midgestation placenta immediately raised the question whether the placenta-derived HSCs are functionally and phenotypically identical to HSCs from other sources. Such information could shed some light on the origin of these cells. We examined the expression of the HSC marker Sca-1 during placental development. Sca-1 has been shown previously to be expressed on all HSCs in the adult bone marrow and foetal liver (Huang and Auerbach, 1993; Spangrude et al. 1988). We generated a transgenic mouse line which expresses the green fluorescent protein (GFP) under the regulatory elements of the Sca-1 gene, $\angle y-6 A$ (de Bruijn et al. 2002). This transgene was found to mark all the HSCs in the AGM, the FL and the adult BM (de Bruijn et al. 2002; Ma et al. 2002). When the expression of the transgene was examined at early developmental stages, we discovered GFP positive cells already at E6 within the extraembryonic ectoderm and the ectoplacental cone (Ottersbach and Dzierzak, 2005). Interestingly, the expression of GFP in the extraembryonic ectoderm was strongest in cells directly adjacent to the epiblast and gradually decreased with increasing distance from the epiblast (Fig. 2). This expression pattern may reflect the location of trophoblast stem cells, which

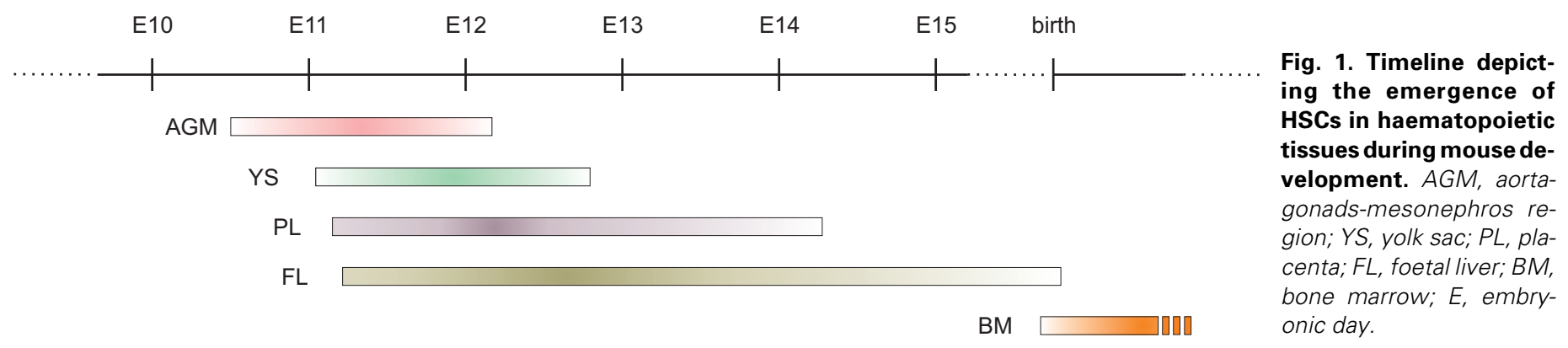


E5.5-6.0

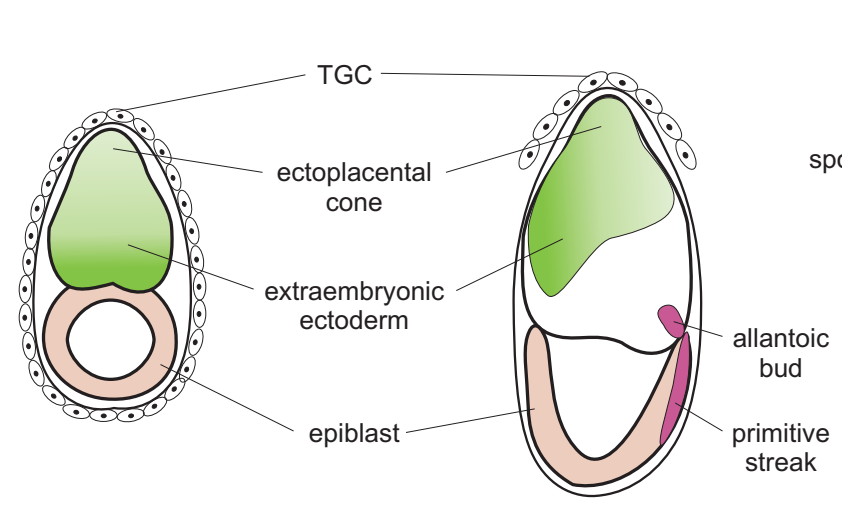

E12

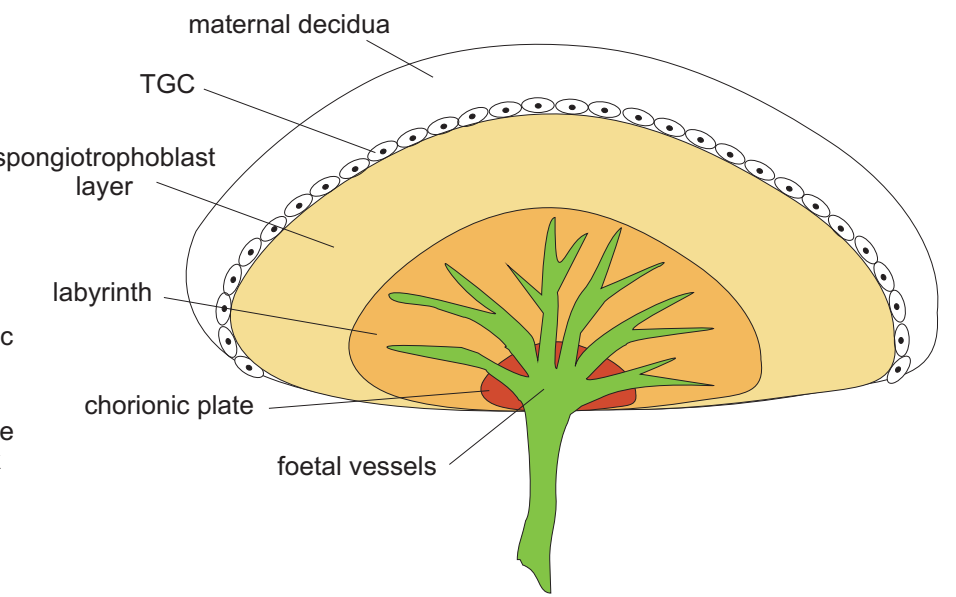

Fig. 2. Schematic diagram of various stages leading up to the development of the fully formed placenta. Tissues that express the Ly- $6 A$ GFP transgene are shown in green. TGC, trophoblast giant cell; E, embryonic day.

are thought to be maintained in a pluripotent state by signals from the embryo and start differentiating as they move towards the ectoplacental cone (reviewed in Rossant and Cross, 2001). Thus, the $\angle y-6 A$ GFP transgene may also mark other types of stem cells. The GFP expression in the ectoplacental cone, the extraembryonic ectoderm and then in the chorionic ectoderm continues into E7 (Fig. 2). Zeigler and colleagues have since then also reported expression of the same transgene in the pre-fusion chorion and allantois following $24 \mathrm{~h}$ of explant culture. While GFP is also detected in the freshly isolated chorion, it only appears in the allantois following this culture step (Zeigler et al. 2006).

The expression of the $\angle y-6 A$ GFP transgene in the precursor tissues of the placenta prompted us to analyse its expression pattern in the fully formed placenta (Ottersbach and Dzierzak, 2005). Surprisingly, the expression of GFP was not maintained in the parts of the placenta that are derived from the extraembryonic ectoderm and the ectoplacental cone (Fig. 2). Instead, we found that the vascular tree of the placental labyrinth, including the umbilical vessels, was highly marked by GFP at all stages analysed (E9-E12, E18; Ottersbach and Dzierzak, 2005, and unpublished data). Furthermore, we found that as with HSCs from other sources, all of the repopulating activity was contained within the Ly-6A GFP+ fraction at E12, the peak of HSC activity in the placenta. The majority of the E12 GFP+ cells also expressed the HSC markers c-kit, CD31 and CD34, and just over $50 \%$ of the $\mathrm{GFP}^{+}$cells carried both c-kit and CD34 on their surface - the classic embryonic HSC signature (Sanchez et al. 1996). It was confirmed by Gekas and colleagues that indeed all of the stem cell activity in the placenta is within the $\mathrm{CD} 34^{+} \mathrm{c}-\mathrm{kit}^{+}$population (Gekas et al. 2005). Although about two thirds of $\mathrm{GFP}^{+}$cells are positive for CD31 and/or CD34 (also expressed on endothelial cells), only one third co-expresses the pan-haematopoietic marker CD45. It is therefore likely that a considerable proportion of the Ly- $6 \mathrm{~A}$ $\mathrm{GFP}^{+}$cells are endothelial cells. Some of these are possibly haemogenic endothelial cells, the putative developmental precursors of HSCs (reviewed in Ottersbach and Dzierzak, 2006). This is partly supported by the observation that, as in the AGM, VEcadherin, a marker for endothelial cells and early HSCs, is progressively downregulated on $\mathrm{CD} 4^{+} \mathrm{c}-\mathrm{kit}^{+}$placental cells
(Taoudi et al. 2005). However, whether there are haemogenic endothelial cells in the placenta needs to be examined, and such studies should provide insight into whether the placenta can autonomously generate HSCs.

Clusters of cells that express haematopoietic as well as endothelial markers (including Ly-6A GFP) and that seem to adhere to the luminal side of major blood vessels, are considered to be signs of HSC generation (reviewed in Ottersbach and Dzierzak, 2006). They appear in the locations and at the time when HSCs can be detected, and they are absent in embryos with genetically impaired HSC production (Cai et al. 2000; Ling et al. 2004). Despite the fact that haematopoietic clusters have been described in the umbilical artery, thus far they have not been detected within the placental vessels. CD41, an integrin of the $\alpha$ subunit family $\left(\alpha_{116}\right)$, has recently been suggested as a marker for nascent HSCs (Bertrand et al. 2008; Corbel and Salaun, 2002; Ferkowicz et al. 2003; Matsubara et al. 2005; Mikkola et al. 2003; Mitjavila-Garcia et al. 2002). We found CD41 expression on approximately one third of E12 Ly-6A GFP+ placental cells, and immunohistochemical staining revealed that $\mathrm{CD} 41^{+}$cells are located within the vessels of the labyrinth, with a few of them attached to the inner vessel wall (Ottersbach and Dzierzak, 2005). This expression pattern was subsequently confirmed by Rhodes and colleagues (Rhodes et al. 2008). CD41-expressing cells are first seen in the pre-fusion allantois as early as the 4-6 somite pair stage (Corbel et al. 2007). Interestingly, CD41 expression was analysed at E10 in embryos defective for the sodium/calcium pump 1 (Ncx1/--), which results in the absence of a heart beat and therefore no blood circulation (Rhodes et al. 2008). Since CD41+ cells were still detected in the mutant placentas, albeit in severely reduced numbers, it suggests that the placenta is capable of generating at least some haematopoietic progenitors. The early death of the Ncx1-/- embryos (E10.5) precluded examination of HSCs in the placenta, which normally appear at E11. The reduced number of CD41+ cells in mutant placentas suggests that a majority of progenitors in a wild-type placenta originate elsewhere or, alternatively, that circulation and shear stress trigger the generation of haematopoietic cells in the placenta. Recent reports have indeed highlighted the role of blood flow-induced sheer stress in 
haematopoietic stem and progenitor cell emergence in the aorta (Adamo et al. 2009; North et al. 2009).

Recently, we have set out to compare the cell surface phenotype of HSCs from different embryonic sources, concentrating in the first instance on members of the integrin family (C. Robin, K. Ottersbach and E. Dzierzak, manuscript in preparation). Integrins are composed of one $\alpha$ and one $\beta$ subunit. Depending on the combination, integrins can interact with different soluble ligands, receptors or extracellular matrix proteins (reviewed in Danen and Sonnenberg, 2003; Kumar, 1998). CD41 ( $\left.\alpha_{\text {Ilb }}\right)$ exclusively pairs with CD61 $\left(\beta_{3}\right)$, which then allows it to interact with several ligands, including von Willebrand Factor and fibronectin. A CD41$\mathrm{CD} 61^{+}$phenotype has recently been described for adult BM HSCs (Ferkowicz et al. 2003; Umemoto et al. 2008). CD61 can also interact with another $\alpha$ subunit, CD51 $\left(\alpha_{v}\right)$, thus opening up studies on another repertoire of ligands that include osteopontin and CD31. Our preliminary results suggest that CD41 is a variable marker of HSCs during development. We are also examining the expression of the other subunits and ligands. Differences in integrin expression may reflect differences in the protein composition of the supportive microenvironment in the various haematopoietic territories of the embryo and/or may also represent different stages of HSC maturation and migration.

The placental expression pattern of a number of haematopoiesis-associated transcription factors has also been examined. Gata2 is essential for HSC generation, as embryos deficient for Gata2 die at E10.5, displaying severe anaemia and a complete absence of HSCs (Ling et al. 2004; Tsai et al. 1994). We initially looked at the expression of this transcription factor in embryos containing a Gata2 lacZ transgene (Zhou etal. 1998). As previously reported (Ma et al. 1997; Ng et al. 1994), we detected Gata2 lacZ expression in some trophoblast giant cells. Gata2 is known to regulate the transcription of the placental hormones placental lactogen I and proliferin and thus, it may influence neovascularisation within the conceptus as well as the adjacent decidual tissue ( $\mathrm{Ng}$ et al. 1994). However, a much more pronounced expression of Gata2 lacZ was seen within the labyrinth, with levels being particularly high on the border to the chorionic plate. We have subsequently confirmed this expression pattern by in situ hybridisation (Fig. 3 B,C white arrow), but have also seen additional expression in cells of the trophoblast lineage within the labyrinth (Fig. 3 B,C). These cells have the appearance of tightly packed cuboidal cells that have been theorised to be labyrinth progenitors and that are preferentially located near the chorionic plate (Fig. 3C, white arrowhead), although evidence in support of this hypothesis is still scarce (Simmons et al. 2008; Wu et al. 2003). Whether Gata2 is also involved in hormone synthesis within these cells and whether this could support vascularisation within the labyrinth or even influence the haematopoietic environment is currently unknown. However, as within the AGM, we also saw endothelial-specific expression of Gata2 in the placenta. It remains to be shown whether this can be taken as evidence for the presence of haemogenic endothelium in the placenta.

The expression of another haematopoietic transcription factor, Gata3, was examined, using a lacZ knock-in mouse line (van Doorninck et al. 1999). Deletion of Gata3 results in embryonic lethality at E11.5, with FL haematopoiesis also being affected (Pandolfi et al. 1995). Like Gata2, Gata3 is known to be expressed in trophoblast giant cells where it also regulates the transcription of trophoblast-specific genes (Ma etal. 1997; Ng etal. 1994). Accordingly, we detected lacZ expression in a few trophoblast giant cells. However, further expression of Gata3 in trophoblast cells within the labyrinth was only revealed by subsequent in situ hybridisation analysis (Fig. 3A). The highly similar expression pattern of Gata2 and Gata3 suggests that they may perform overlapping functions in the placenta.

The transcription factor Runx1 is essential for HSC generation during development, and Runx1-null embryos die at E12.5 due to a complete disruption of definitive haematopoiesis (Okuda et al. 1996; Wang et al. 1996). Its expression during development has been mainly studied in a lacZ knock-in mouse line (North et al. 1999). Expression from this allele can already be seen in isolated mesodermal cells in the chorion at the early bud stage (Zeigler et al. 2006). A limited number of Runx1-expressing cells can also be observed in the distal and proximal regions of the pre-fusion allantois, although explant cultures of sub-divided allantoic tissues demonstrated that Runx1 expression can be initiated in cells throughout the entire allantois. After chorio-allantoic fusion, Runx $1^{+}$ cells were detected at the fusion interface and also in the proximal allantoic vasculature (Zeigler etal.2006). The expression of Runx1 by RT-PCR analysis of the fully formed placenta was first reported by Alvarez-Silva and colleagues (Alvarez-Silva et al. 2003). Using the Runx $1^{\mathrm{lz}}$ allele, we subsequently assigned the expression to cells in the chorionic plate and, within the labyrinth, to endothelial cells, individual cells and clusters of cells in the circulation and to cells just underneath the placental vessels (Ottersbach and
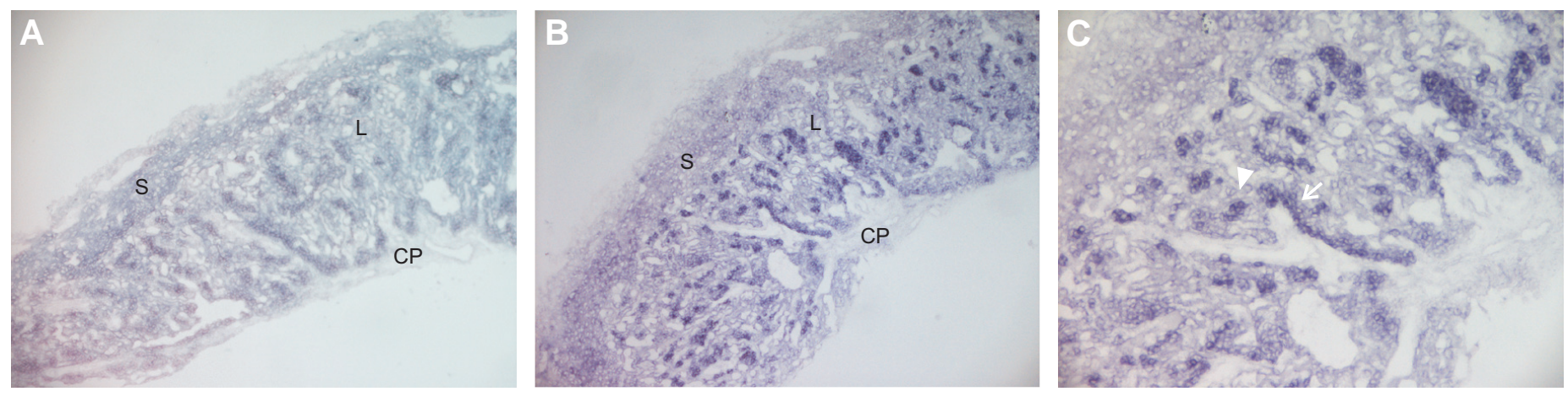

Fig. 3. Gata2 and Gata3 expression in the placenta. In situ hybridisation on E11 placenta sections with riboprobes for (A) Gata3 and (B,C) Gata2. $(C)$ is a close-up of (B). White arrow, strong Gata2 expression near chorionic plate; white arrowhead, Gata2+ cuboidal cells. CP, chorionic plate; $L$, labyrinth; $S$, spongiotrophoblast layer. 
Dzierzak, 2005). This pattern is similar to the one found in the AGM where Runx1 is known to be essential for the formation of HSCs (Cai et al. 2000; North et al. 1999; North et al. 2002). This pattern of Runx1 expression in the placenta was subsequently confirmed by Rhodes and colleagues (Rhodes et al. 2008). They also reported that the Run $\times 1^{+}$cells within the placental vessels were more mitotically active than the ones in the AGM, thus supporting the notion that the placenta acts as a site of HSC expansion. While deletion of Runx1 results in a complete lack of HSCs, a half dose of Runx1 results in a spatial and temporal shift of HSC emergence (Cai et al. 2000). HSCs appear earlier in both AGM and YS of Runx1+/- embryos as shown by direct transplantation of freshly isolated tissues. However, when these tissues are subjected to an explant culture step, it becomes apparent that HSCs in the AGM cannot be maintained, with numbers already severely reduced at E10 and then disappearing thereafter (Cai et al. 2000). In contrast, haploinsufficient YS explants show increased HSC numbers at $\mathrm{E} 10$ and $\mathrm{E} 11$. We have recently included the placenta in this analysis and found that the phenotype is similar to the YS: HSC numbers are increased in E11 Runx1+/- placenta explants as compared with wild-type tissues (Robin et al. 2006). We have also observed an early appearance of HSCs in E10 Runx1+/- placentas (Robin et al. 2006; unpublished data). Therefore, a full dose of Runx1 has a negative effect on HSC appearance in the YS and placenta, while promoting HSC activity in the AGM. Interestingly, placental HSCs are indistinguishable from YS and AGM HSCs (Runx1+/+ and Runx1+/-) in their response to the growth factor Interleukin-3 (IL-3), with numbers increasing dramatically after explant culture in the presence of recombinant IL-3 (Robin et al. 2006). These results perhaps indicate important differences in the intraembryonic haematopoietic microenvironment.

In summary, placental HSCs share the common phenotype of Ly6A ${ }^{+} \mathrm{CD} 34{ }^{+} \mathrm{C}-\mathrm{kit}^{+}$with AGM HSCs. However, there are some differences in HSC growth in different parts of the conceptus which are revealed by the analysis of embryos haploinsufficient for pivotal hematopoietic transcription factors. In many aspects placental HSCs are more similar to YS HSCs. Finding a functional explanation for these differences and uncovering further dissimilarities between embryonic haematopoietic sites, should clarify the significance of having multiple haematopoietic sites during development.

\section{Placenta microenvironment}

The main function of the placenta is the exchange of nutrients, gases and waste products between the foetal and maternal circulation. This takes place within the placental labyrinth, and mutations that affect the development of this vascularised part of the placenta, where HSCs are known to reside (Ottersbach and Dzierzak, 2005), can have serious consequences for the foetus, ranging from growth retardation to midgestational lethality (reviewed in Watson and Cross, 2005). The placenta is also an endocrine organ that produces an array of hormones from its trophoblast cells (reviewed in Linzer and Fisher, 1999). Some of these hormones are known to influence vascularisation in the maternal as well as the foetal part of the placenta (Ma et al. 1997; $\mathrm{Ng}$ et al. 1994). Such hormones may impact on placental haematopoiesis, as haematopoietic and endothelial development are tightly linked (reviewed in Ottersbach and Dzierzak, 2006). Other hormones are also likely to affect haematopoiesis directly (reviewed in Linzer and Fisher, 1999). It was reported many years ago that the human placenta releases haematopoietic growth factors that promote haematopoietic colony formation (Burgess et al. 1977), thus indicating that the placenta supports haematopoiesis. In addition to hormones and growth factors being directly produced and secreted by placental trophoblast cells, it is also likely that maternally derived factors enter the placenta via a number of transporters found at the junction of the maternal and foetal circulation. It was recently demonstrated that maternal loss of the transcriptional repressor Tgif results in a defect in foetal placental vasculature development (Bartholin et al. 2008). The molecular details of this observation are currently unclear, but it clearly proves that maternal processes can indeed affect the formation of foetalderived placental structures.

The first indication that the placenta has a microenvironment suitable for the maintenance and expansion of a wide range of haematopoietic progenitors came from work carried out by Françoise Dieterlen-Lièvre's group (Alvarez-Silva et al. 2003). These authors demonstrated that clonogenic progenitors appeared in the placenta as early as E9, slightly later than in the embryo proper and the YS. Up to E12, total colony numbers in the placenta are even more numerous than in the FL. Their frequency remains above that found in the FL for the rest of development, and the progenitors in the placenta seem to have a more immature phenotype. However, after E13, there seems to be a change in the supportive environment since the number of progenitors and HSCs in the placenta declines (Gekas et al. 2005). Even an attempt to enrich for HSCs by sorting Ly-6A GFP ${ }^{+}$cells from E18 (term) placentas did not yield any HSC activity (K. Ottersbach and E. Dzierzak, unpublished data). It is currently unclear what causes the decline in placental haematopoietic support, but an identification of the components that make up the haematopoietic microenvironment is likely to offer some explanations.

A candidate cell lineage providing haematopoietic support in the placenta niche may be mesenchymal stem/stromal cells, as these have been linked to haematopoietic support in other tissues (Mendes et al. 2005; Sacchetti et al. 2007). Indeed, Zhang and colleagues have isolated mesenchymal progenitor cells from the human placenta that are capable of expanding long-term cultureinitiating cells from cord blood-derived CD34+ cells (Zhang et al. 2004). We also have derived mesenchymal stromal cell lines from the human placenta (Robin et al. 2009) and mouse placenta (I. Lauw, Master of Science thesis) from several stages of development. Some of these showed an extensive mesenchymal differentiation potential and also displayed a pericyte/perivascular cell phenotype similar to cells that have recently been reported to be the in vivo counterpart of mesesenchymal stromal/stem cells (Crisan et al. 2008). Furthermore, these stromal cells also had the capacity to expand haematopoietic progenitor cells from human cord blood in coculture experiments (Robin et al. 2009). Thus, the placenta appears to contain stromal cells indicative of a haematopoietic niche throughout gestation, suggesting that in vivo the microenvironment of the placenta is conducive to haematopoietic maintenance and growth.

\section{The human placenta}

Many aspects of HSC development are conserved between the mouse and the human conceptus. Since the mouse placenta 
was shown to generate haematopoietic progenitors early in development, and from midgestation on to contain an abundance of haematopoietic progenitors and HSCs, it is of great interest to determine whether the human placenta is a potential source of haematopoietic progenitors and HSCs. The human placenta, as a resource for human cells and factors, has thus far found little medical application. It is a rest tissue and is usually discarded at birth. Recently, we examined the haematopoietic potential of the human placenta at a series of developmental time points, including term (Robin et al. 2009). As measured by in vitro clonogenic activity, foetal-derived haematopoietic progenitors are present in the placenta as early as week 6 in gestation. Initially progenitors are in both CD34 ${ }^{-}$and CD34+ fractions, but by week 15 all progenitors are $\mathrm{CD}_{34}{ }^{+}$. The presence of $\mathrm{CD} 34^{+}$progenitor cells in the human placenta from week 8 has also been reported by Barcena et al. (Barcena et al. 2009 a,b). Moreover, using NOD-SCID mouse transplantation assays, we also found potent multilineage, high level repopulating cells to be present in the human placenta (Robin et al. 2009). HSCs are detected beginning at week 6 of gestation and throughout trimesters 1 and 2 and also in term placenta. These cells are foetal-derived and based on the extraction method, some are with the vascular fraction. Considering the lack of HSCs in the term mouse placenta (Gekas et al. 2005; K. Ottersbach and E. Dzierzak, unpublished data), the finding of HSCs in the human term placenta is surprising and suggests that this normally discarded rest tissue has potential medical value.

The presence of HSCs in the human placenta now focuses attention on how the haematopoietic growth properties of this tissue can be exploited. As mentioned above, efforts should concentrate on identifying the factors that are responsible for the remarkable ability of the placenta to expand HSCs. Such factors can be utilised to increase human HSC numbers ex vivo for cell replacement therapies. It is also likely that placental HSCs are similar to cord blood-derived HSCs. Cord blood HSCs are known to be more naive than adult bone marrow HSCs, thus allowing less stringent criteria for HLA matching and resulting in availability of these cells to a much wider population. These cells also appear to have a lower transmission rate of infectious and genetic diseases (Benito et al. 2004; Cohen and Nagler 2004 a,b; de Vries et al. 2004). Thus, human placental HSCs together with umbilical cord blood cells, could offer a quantitatively higher number of such cells for replacement therapies. Finally, the placenta as a HSC niche may also be important in the context of leukaemia aetiology, since transplacental chemical agents have been put forward as possible causes for acute infant leukaemia (reviewed in Greaves, 2006). As there is some evidence suggesting that infantile hemangioma may be of placental origin (Barnes et al. 2005), placental HSCs may represent the initial target for these transforming agents.

\section{Concluding remarks}

Often in seminars the question arises 'why there are HSCs in the placenta in the first place'. Non-mammalian vertebrate species, such as chicken, zebrafish and frog, in which blood development has also been intensely studied, have a well-functioning haematopoietic system in the absence of a placenta. Yet the processes of blood development are highly conserved amongst all these vertebrate species (reviewed in Cumano and Godin, 2007; Dzierzak and Speck, 2008). It has been suggested that more than one source is required to provide sufficient numbers of HSCs for the colonisation of the FL (Kumaravelu et al. 2002). Therefore, has the placenta evolved as an external HSC territory to provide larger quantities of HSCs and progenitors than the YS and AGM are capable of producing? Perhaps the growth factor- and hormonerich, vascularised placental niche encourages the proliferation of HSCs migrating from the AGM via the umbilical vessels to the FL. This possibility is supported by the observation in the mouse that HSCs become detectable in the placenta nearly a day after they emerge in the AGM and their numbers decline again rapidly a day after HSC production in the AGM stops (the AGM ceases to exist as an entity after E12). Therefore, as HSC production and migration in the mouse embryo is terminated and the FL is fully colonised, the flow of HSCs through the placenta also stops and HSCs can no longer be detected there. Also, the gross morphology of the placenta does not seem to change dramatically after HSC numbers decline at E13. Thus, it may not be a change in the haematopoietic environment in the placenta that causes HSCs to disappear. Indeed, mouse placenta-derived haematopoietic progenitors remain numerous after E13 (Alvarez-Silva et al. 2003), and haematopoietic supportive stromal cell lines have been isolated from human placenta throughout development. However, in the mouse it would be interesting to examine if stromal cell lines derived from the placenta at later developmental stages have the same supportive capacity as stromal cell lines derived at the peak of HSC expansion in the placenta.

Another possibility is that HSCs arise in the placenta. CD41 ${ }^{+}$ haematopoietic cells were found in the placenta in the absence of cellular exchange between different tissues via the circulation (Rhodes et al. 2008), and at the early stages of normal placenta development the allantois and chorion possess haematopoietic potential (Corbel etal. 2007; Zeigler etal.2006). The fact that some placental HSCs have a phenotype suggestive of an endothelial origin (Ottersbach and Dzierzak, 2005; Taoudi et al. 2005) supports the possibility that some HSCs are derived from placental haemogenic endothelium. Thus, whether the placenta is another example of the recurrent theme of HSC generation along the major vasculature of the conceptus awaits lineage tracing experiments and in vivo imaging.

The placenta as a HSC niche was only reported in the mouse five years ago and little is currently known about the cellular and molecular mechanisms regulating haematopoietic activity within this tissue, particularly in the human. Once some of the niche components have been identified, it may be possible to utilise this information to specifically disrupt placental haematopoiesis and hence reveal the relative importance of the placenta in foetal haematopoiesis.

\section{Acknowledgements}

We would like to acknowledge the following funding agencies for their financial support, The Wellcome Trust (GR063331MA), The Kay Kendall Leukaemia Fund (KKL276), Netherlands VICI ZonMW (916.36.6001), Netherlands BSIK 03038 SCDD Award, Landsteiner Society for Blood Research (0614) and NIH (R37DK054077).

\section{References}

ADAMO, L., NAVEIRAS, O., WENZEL, P.L., MCKINNEY-FREEMAN, S., MACK, P.J., GRACIA-SANCHO, J., SUCHY-DICEY, A., YOSHIMOTO, M., LENSCH, M.W., YODER, M.C., et al. (2009). Biomechanical forces promote embryonic 
haematopoiesis. Nature 459: 1131-1135

ADOLFSSON, J., MANSSON, R., BUZA-VIDAS, N., HULTQUIST, A., LIUBA, K., JENSEN, C.T., BRYDER, D., YANG, L., BORGE, O.J., THOREN, L.A., et al. (2005). Identification of Flt3+ lympho-myeloid stem cells lacking erythro-megakaryocytic potential a revised road map for adult blood lineage commitment. Cel/ 121: 295-306.

ALVAREZ-SILVA, M., BELO-DIABANGOUAYA, P., SALAUN, J., DIETERLENLIEVRE, F. (2003). Mouse placenta is a major hematopoietic organ. Development 130: 5437-5444.

BARCENA, A., KAPIDZIC, M., MUENCH, M.O., GORMLEY, M., SCOTT, M.A., WEIER, J.F., FERLATTE, C., FISHER, S.J. (2009a). The human placenta is a hematopoietic organ during the embryonic and fetal periods of development. Dev Bio/327: 24-33.

BARCENA, A., MUENCH, M.O., KAPIDZIC, M., FISHER, S.J. (2009b). A new role for the human placenta as a hematopoietic site throughout gestation. Reprod Sci(Thousand Oaks, Calif) 16: 178-187.

BARNES, C.M., HUANG, S., KAIPAINEN, A., SANOUDOU, D., CHEN, E.J., EICHLER, G.S., GUO, Y., YU, Y., INGBER, D.E., MULLIKEN, J.B., etal. (2005). Evidence by molecular profiling for a placental origin of infantile hemangioma. Proc Natl Acad Sci USA 102: 19097-19102.

BARTHOLIN, L., MELHUISH, T.A., POWERS, S.E., GODDARD-LEON, S., TREILLEUX, I., SUTHERLAND, A.E., WOTTON, D. (2008). Maternal Tgif is required for vascularization of the embryonic placenta. Dev Bio/319: 285-297.

BELL, J.J., BHANDOOLA, A. (2008). The earliest thymic progenitors for T cells possess myeloid lineage potential. Nature 452: 764-767.

BENITO, A.I., DIAZ, M.A., GONZALEZ-VICENT, M., SEVILLA, J., MADERO, L. (2004). Hematopoietic stem cell transplantation using umbilical cord blood progenitors: review of current clinical results. Bone Marrow Transp/33: 675690.

BERTRAND, J.Y., KIM, A.D., TENG, S., TRAVER, D. (2008). CD41+ cmyb+ precursors colonize the zebrafish pronephros by a novel migration route to initiate adult hematopoiesis. Development 135: 1853-1862.

BURGESS, A.W., WILSON, E.M., METCALF, D. (1977). Stimulation by human placental conditioned medium of hemopoietic colony formation by human marrow cells. Blood 49: 573-583.

CAI, Z., DE BRUIJN, M., MA, X., DORTLAND, B., LUTEIJN, T., DOWNING, R.J., DZIERZAK, E. (2000). Haploinsufficiency of AML1 affects the temporal and spatial generation of hematopoietic stem cells in the mouse embryo. Immunity 13: $423-431$

CAPRIOLI, A., JAFFREDo, T., GAUtieR, R., DUBOURG, C., DIETERLENLIEVRE, F. (1998). Blood-borne seeding by hematopoietic and endothelial precursors from the allantois. Proc Natl Acad Sci USA 95: 1641-1646.

CAPRIOLI, A., MINKO, K., DREVON, C., EICHMANN, A., DIETERLEN-LIEVRE, F., JAFFREDO, T. (2001). Hemangioblast commitment in the avian allantois: cellular and molecular aspects. Dev Bio/238: 64-78.

COHEN, Y., NAGLER, A. (2004a). Cord blood biology and transplantation. /sr Med Assoc J6: 39-46.

COHEN, Y., NAGLER, A. (2004b). Umbilical cord blood transplantation-how, when and for whom? Blood Rev 18: 167-179.

CORBEL, C., SALAUN, J. (2002). Alphallb integrin expression during development of the murine hemopoietic system. Dev Bio/243: 301-311.

CORBEL, C., SALAUN, J., BELO-DIABANGOUAYA, P., DIETERLEN-LIEVRE, F. (2007). Hematopoietic potential of the pre-fusion allantois. Dev Bio/301: 478488.

CRISAN, M., YAP, S., CASTEILLA, L., CHEN, C.W., CORSELLI, M., PARK, T.S., ANDRIOLO, G., SUN, B., ZHENG, B., ZHANG, L., et al. (2008). A perivascular origin for mesenchymal stem cells in multiple human organs. Ce// Stem Cel/3: 301-313.

CROSS, J.C., BACZYK, D., DOBRIC, N., HEMBERGER, M., HUGHES, M., SIMMONS, D.G., YAMAMOTO, H., KINGDOM, J.C. (2003). Genes, development and evolution of the placenta. Placenta 24: 123-130.

CUMANO, A., DIETERLEN-LIEVRE, F., GODIN, I. (1996). Lymphoid potential, probed before circulation in mouse, is restricted to caudal intraembryonic splanchnopleura. Ce//86: 907-916.

CUMANO, A., GODIN, I. (2007). Ontogeny of the hematopoietic system. Annu Rev
Immuno/25: 745-785.

DANEN, E.H., SONNENBERG, A. (2003). Integrins in regulation of tissue development and function. J Patho/200: 471-480.

DE BRUIJN, M.F., MA, X., ROBIN, C., OTTERSBACH, K., SANCHEZ, M.J. DZIERZAK, E. (2002). Hematopoietic stem cells localize to the endothelial cell layer in the midgestation mouse aorta. Immunity 16: 673-683.

DE VRIES, E.G., VELLENGA, E., KLUIN-NELEMANS, J.C., MULDER, N.H. (2004). The happy destiny of frozen haematopoietic stem cells: from immature stem cells to mature applications. Eur J Cancer 40: 1987-1992.

DIETERLEN-LIEVRE, F. (1975). On the origin of haemopoietic stem cells in the avian embryo: an experimental approach. J Embryo/ Exp Morpho/33: 607-619.

DOWNS, K.M., GIFFORD, S., BLAHNIK, M., GARDNER, R.L. (1998). Vascularization in the murine allantois occurs by vasculogenesis without accompanying erythropoiesis. Development 125: 4507-4520.

DOWNS, K.M., HARMANN, C. (1997). Developmental potency of the murine allantois. Development 124: 2769-2780.

DZIERZAK, E., SPECK, N.A. (2008). Of lineage and legacy: the development of mammalian hematopoietic stem cells. Nat Immuno/9: 129-136.

FERKOWICZ, M.J., STARR, M., XIE, X., LI, W., JOHNSON, S.A., SHELLEY, W.C., MORRISON, P.R., YODER, M.C. (2003). CD41 expression defines the onset of primitive and definitive hematopoiesis in the murine embryo. Development 130 : 4393-4403.

GEKAS, C., DIETERLEN-LIEVRE, F., ORKIN, S.H., MIKKOLA, H.K. (2005). The placenta is a niche for hematopoietic stem cells. Dev Cel/8: 365-375.

GREAVES, M. (2006). Infection, immune responses and the aetiology of childhood leukaemia. Nat Rev Cancer6: 193-203.

HUANG, H., AUERBACH, R. (1993). Identification and characterization of hematopoietic stem cells from the yolk sac of the early mouse embryo. Proc Nat/ Acad Sci USA 90: 10110-10114.

KUMAR, C.C. (1998). Signaling by integrin receptors. Oncogene 17: 1365-1373.

KUMARAVELU, P., HOOK, L., MORRISON, A.M., URE, J., ZHAO, S., ZUYEV, S. ANSELL, J., MEDVINSKY, A. (2002). Quantitative developmental anatomy of definitive haematopoietic stem cells/long-term repopulating units (HSC/RUs): role of the aorta-gonad-mesonephros (AGM) region and the yolk sac in colonisation of the mouse embryonic liver. Development 129: 4891-4899.

LING, K.W., OTTERSBACH, K., VAN HAMBURG, J.P., OZIEMLAK, A., TSAI, F.Y., ORKIN, S.H., PLOEMACHER, R., HENDRIKS, R.W., DZIERZAK, E. (2004). GATA-2 plays two functionally distinct roles during the ontogeny of hematopoietic stem cells. J Exp Med200: 871-882.

LINZER, D.I., FISHER, S.J. (1999). The placenta and the prolactin family of hormones: regulation of the physiology of pregnancy. Mol Endocrino/ 13: 837840.

MA, G.T., ROTH, M.E., GROSKOPF, J.C., TSAI, F.Y., ORKIN, S.H., GROSVELD, F., ENGEL, J.D., LINZER, D.I. (1997). GATA-2 and GATA-3 regulate trophoblast-specific gene expression in vivo. Development 124: 907-914.

MA, X., ROBIN, C., OTTERSBACH, K., DZIERZAK, E. (2002). The Ly-6A (Sca-1) GFP transgene is expressed in all adult mouse hematopoietic stem cells. Stem Cells 20: 514-521.

MATSUBARA, A., IWAMA, A., YAMAZAKI, S., FURUTA, C., HIRASAWA, R., MORITA, Y., OSAWA, M., MOTOHASHI, T., ETO, K., EMA, H., et al. (2005). Endomucin, a CD34-like sialomucin, marks hematopoietic stem cells throughout development. J Exp Med202: 1483-1492.

MEDVINSKY, A., DZIERZAK, E. (1996). Definitive hematopoiesis is autonomously initiated by the AGM region. Ce//86: 897-906.

MENDES, S.C., ROBIN, C., DZIERZAK, E. (2005). Mesenchymal progenitor cells localize within hematopoietic sites throughout ontogeny. Development 132 1127-1136.

MIKKOLA, H.K., FUJIWARA, Y., SCHLAEGER, T.M., TRAVER, D., ORKIN, S.H. (2003). Expression of CD41 marks the initiation of definitive hematopoiesis in the mouse embryo. Blood 101: 508-516.

MITJAVILA-GARCIA, M.T., CAILLERET, M., GODIN, I., NOGUEIRA, M.M., COHENSOLAL, K., SCHIAVON, V., LECLUSE, Y., LE PESTEUR, F., LAGRUE, A.H., VAINCHENKER, W. (2002). Expression of CD41 on hematopoietic progenitors derived from embryonic hematopoietic cells. Development 129: 2003-2013.

MOORE, M.A., METCALF, D. (1970). Ontogeny of the haemopoietic system: yolk 
sac origin of in vivo and in vitro colony forming cells in the developing mouse embryo. Br J Haemato/ 18: 279-296.

MULLER, A.M., MEDVINSKY, A., STROUBOULIS, J., GROSVELD, F., DZIERZAK, E. (1994). Development of hematopoietic stem cell activity in the mouse embryo. Immunity 1: 291-301.

NG, Y.K., GEORGE, K.M., ENGEL, J.D., LINZER, D.I. (1994). GATA factor activity is required for the trophoblast-specific transcriptional regulation of the mouse placental lactogen I gene. Development 120: 3257-3266.

NORTH, T., GU, T.L., STACY, T., WANG, Q., HOWARD, L., BINDER, M., MARINPADILLA, M., SPECK, N.A. (1999). Cbfa2 is required for the formation of intraaortic hematopoietic clusters. Development 126: 2563-2575.

NORTH, T.E., DE BRUIJN, M.F., STACY, T., TALEBIAN, L., LIND, E., ROBIN, C., BINDER, M., DZIERZAK, E., SPECK, N.A. (2002). Runx1 expression marks long-term repopulating hematopoietic stem cells in the midgestation mouse embryo. Immunity 16: 661-672.

NORTH, T.E., GOESSLING, W., PEETERS, M., LI, P., CEOL, C., LORD, A.M., WEBER, G.J., HARRIS, J., CUTTING, C.C., HUANG, P., et al. (2009). Hematopoietic stem cell development is dependent on blood flow. Cel/137: 736-748.

OKUDA, T., VAN DEURSEN, J., HIEBERT, S.W., GROSVELD, G., DOWNING, J.R. (1996). AML1, the target of multiple chromosomal translocations in human leukemia, is essential for normal fetal liver hematopoiesis. Ce//84: 321-330.

OTTERSBACH, K., DZIERZAK, E. (2005). The murine placenta contains hematopoietic stem cells within the vascular labyrinth region. Dev Ce//8: 377-387.

OTTERSBACH, K., DZIERZAK, E. (2006). The Endothelium - the Cradle of Definitive Hematopoiesis? In Hematopoietic Stem Cell Development (Eds. I. Godin and A. Cumano) Landes Bioscience, Georgetown, pp. 80-91.

PANDOLFI, P.P., ROTH, M.E., KARIS, A., LEONARD, M.W., DZIERZAK, E., GROSVELD, F.G., ENGEL, J.D., LINDENBAUM, M.H. (1995). Targeted disruption of the GATA3 gene causes severe abnormalities in the nervous system and in fetal liver haematopoiesis. Nat Genet 11: 40-44.

RHODES, K.E., GEKAS, C., WANG, Y., LUX, C.T., FRANCIS, C.S., CHAN, D.N., CONWAY, S., ORKIN, S.H., YODER, M.C., MIKKOLA, H.K. (2008). The emergence of hematopoietic stem cells is initiated in the placental vasculature in the absence of circulation. Cel/ Stem Ce//2: 252-263.

ROBIN, C., BOLLEROT, K., MENDES, S., HAAK, E., CRISAN, M., CERISOLI, F. LAUW, I., KAIMAKIS, P., JORNA, R., VERMEULEN, M., et al. (2009). Human placenta is a potent hematopoietic niche containing hematopoietic stem and progenitor cells throughout development. Cel/ Stem Ce//5: 385-395.

ROBIN, C., OTTERSBACH, K., DURAND, C., PEETERS, M., VANES, L., TYBULEWICZ, V., DZIERZAK, E. (2006). An unexpected role for IL-3 in the embryonic development of hematopoietic stem cells. Dev Cel/11: 171-180.

ROSSANT, J., CROSS, J.C. (2001). Placental development: lessons from mouse mutants. Nat Rev 2: 538-548.

SACCHETTI, B., FUNARI, A., MICHIENZI, S., DI CESARE, S., PIERSANTI, S., SAGGIO, I., TAGLIAFICO, E., FERRARI, S., ROBEY, P.G., RIMINUCCI, M., et al. (2007). Self-renewing osteoprogenitors in bone marrow sinusoids can organize a hematopoietic microenvironment. Cel/131: 324-336.

SANCHEZ, M.J., HOLMES, A., MILES, C., DZIERZAK, E. (1996). Characterization of the first definitive hematopoietic stem cells in the AGM and liver of the mouse embryo. Immunity 5: 513-525.

SIMMONS, D.G., NATALE, D.R., BEGAY, V., HUGHES, M., LEUTZ, A., CROSS,
J.C. (2008). Early patterning of the chorion leads to the trilaminar trophoblast cell structure in the placental labyrinth. Development 135: 2083-2091.

SPANGRUDE, G.J., HEIMFELD, S., AND WEISSMAN, I.L. (1988). Purification and characterization of mouse hematopoietic stem cells. Science (New York, NY) 241: 58-62.

TAOUDI, S., MORRISON, A.M., INOUE, H., GRIBI, R., URE, J., MEDVINSKY, A. (2005). Progressive divergence of definitive haematopoietic stem cells from the endothelial compartment does not depend on contact with the foetal liver Development 132, 4179-4191.

TSAI, F.Y., KELLER, G., KUO, F.C., WEISS, M., CHEN, J., ROSENBLATT, M. ALT, F.W., ORKIN, S.H. (1994). An early haematopoietic defect in mice lacking the transcription factor GATA-2. Nature 371: 221-226.

UMEMOTO, T., YAMATO, M., SHIRATSUCHI, Y., TERASAWA, M., YANG, J., NISHIDA, K., KOBAYASHI, Y., OKANO, T. (2008). CD61 enriches long-term repopulating hematopoietic stem cells. Bioch Bioph Res Co 365: 176-182.

VAN DOORNINCK, J.H., VAN DER WEES, J., KARIS, A., GOEDKNEGT, E., ENGEL, J.D., COESMANS, M., RUTTEMAN, M., GROSVELD, F., DE ZEEUW, C.I. (1999). GATA-3 is involved in the development of serotonergic neurons in the caudal raphe nuclei. JNeurosci19: RC12.

WADA, H., MASUDA, K., SATOH, R., KAKUGAWA, K., IKAWA, T., KATSURA, Y. KAWAMOTO, H. (2008). Adult T-cell progenitors retain myeloid potential. Nature 452: 768-772.

WANG, Q., STACY, T., BINDER, M., MARIN-PADILLA, M., SHARPE, A.H. SPECK, N.A. (1996). Disruption of the Cbfa2 gene causes necrosis and hemorrhaging in the central nervous system and blocks definitive hematopoiesis. Proc Natl Acad Sci USA 93: 3444-3449

WATSON, E.D., CROSS, J.C. (2005). Development of structures and transport functions in the mouse placenta. Physiology 20: 180-193.

WEISSMAN, I., PAPAIOANNOU, V., GARDNER, R. (1978). Fetal hematopoietic origins of the adult hematolymphoid system. In Differentiation of Normal and Neoplastic Hematopoietic Cells (Ed. B. Clarkson, P.A. Marks, J.E. Till), Cold Spring Harbor Laboratory Press, New York, pp. 33-47

WEISSMAN, I.L., SHIZURU, J.A. (2008). The origins of the identification and isolation of hematopoietic stem cells, and their capability to induce donorspecific transplantation tolerance and treat autoimmune diseases. Blood 112 3543-3553.

WU, L., DE BRUIN, A., SAAVEDRA, H.I., STAROVIC, M., TRIMBOLI, A., YANG, Y., OPAVSKA, J., WILSON, P., THOMPSON, J.C., OSTROWSKI, M.C., et al. (2003). Extra-embryonic function of $\mathrm{Rb}$ is essential for embryonic development and viability. Nature 421: 942-947.

ZEIGLER, B.M., SUGIYAMA, D., CHEN, M., GUO, Y., DOWNS, K.M., SPECK, N.A (2006). The allantois and chorion, when isolated before circulation or chorioallantoic fusion, have hematopoietic potential. Development 133: 4183-4192.

ZHANG, Y., LI, C., JIANG, X., ZHANG, S., WU, Y., LIU, B., TANG, P., MAO, N (2004). Human placenta-derived mesenchymal progenitor cells support culture expansion of long-term culture-initiating cells from cord blood CD34+cells. Exp Hemato/32: 657-664.

ZHOU, Y., LIM, K.C., ONODERA, K., TAKAHASHI, S., OHTA, J., MINEGISHI, N., TSAI, F.Y., ORKIN, S.H., YAMAMOTO, M., ENGEL, J.D. (1998). Rescue of the embryonic lethal hematopoietic defect reveals a critical role for GATA-2 in urogenital development. EMBO J17: 6689-6700. 


\section{Further Related Reading, published previously in the Int. J. Dev. Biol.}

See our recent Special Issue Placenta edited by Joan S. Hunt and Kent L. Thornburg at: http://www.ijdb.ehu.es/web/contents.php?vol=54\&issue=2-3

\section{Placenta}

Joan S. Hunt and Kent L. Thornburg

Int. J. Dev. Biol. (2010) 54: 227-229

Tracing the hemangioblast during embryogenesis: developmental relationships between endothelial and hematopoietic cells Thierry Jaffredo, Karine Bollerot, Daisuke Sugiyama, Rodolphe Gautier and Cécile Drevon

Int. J. Dev. Biol. (2005) 49: 269-277

\section{Of birds and mice: hematopoietic stem cell development}

Isabelle Godin and Ana Cumano

Int. J. Dev. Biol. (2005) 49: 251-257

Embryonic development of the human hematopoietic system Manuela Tavian and Bruno Péault

Int. J. Dev. Biol. (2005) 49: 243-250

Commitment of hematopoietic stem cells in avian and mammalian embryos: an ongoing story Françoise Dieterlen-Lièvre

Int. J. Dev. Biol. (2005) 49: 125-130
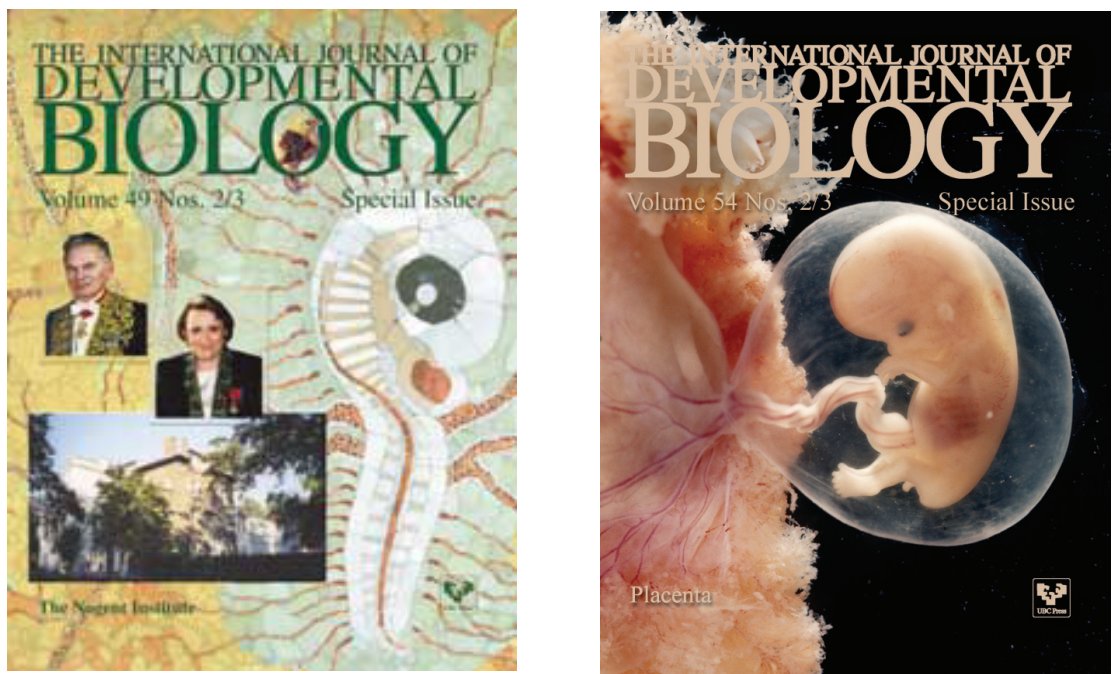

5 yr ISI Impact Factor (2009) = 3.253

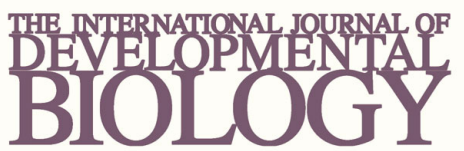

Volume 54 Nos. 6/7

Special Issue

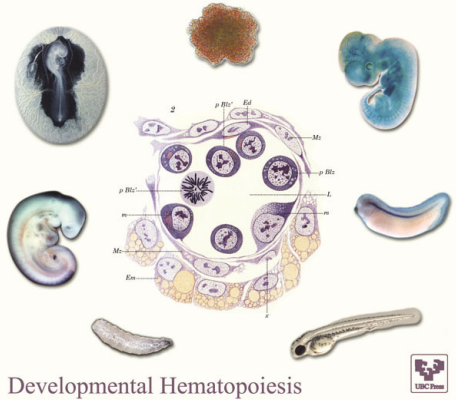

Developmental Hematopoiesis 